\title{
Effect of soaking temperature on soaking characteristics of soybean (Glycine max) during rehydration process
}

\author{
Hyeon Woo Park ${ }^{1}$ - Won Young Han ${ }^{2}$ - Won Byong Yoon ${ }^{1}$

\section{콩의 수화 공정에서 수화 온도에 따른 콩(Glycine $\max )$ 의 수화 및 단백질 용출 특성}

박현우 ${ }^{1}$ - 한원영 ${ }^{2}$ - 윤원병 ${ }^{1}$

Received: 14 July 2019 / Accepted: 5 August 2019 / Published Online: 30 September 2019

(C) The Korean Society for Applied Biological Chemistry 2019

\begin{abstract}
The effect of soaking temperature on the moisture uptake and the protein loss of soybeans during soaking process investigated. As the soaking temperature increased, the soaking rate significantly increased and Peleg model was suitable for describing the soaking characteristics of the soybean with high $R^{2}$ values $(>0.991)$. The soaking time to achieve the target moisture content of soybean $(130 \%)$ was estimated to be $12.6,3.11$ and $2.31 \mathrm{~h}$ at 25,35 and $45^{\circ} \mathrm{C}$, respectively. Peleg model well described the protein loss kinetics of soybean during soaking with high $R^{2}$ values $(>0.941)$. The results showed that the protein loss of soybean at the target moisture content were 35.2, 93.1 and $103.0 \mathrm{mg} / \mathrm{g}$ at 25,35 and $45^{\circ} \mathrm{C}$, respectively. In this study, the optimum soaking condition for quality of soybean was $12.6 \mathrm{~h}$ of soaking time at $25^{\circ} \mathrm{C}$.
\end{abstract}

Keywords Hydration - Soaking process - Moisture diffusion Protein loss

Won Byong Yoon $(\square)$

E-mail:wbyoon@kangwon.ac.kr

${ }^{1}$ Department of Food Science and Biotechnology, College of Agricultural and Life Science, Kangwon National University, Chuncheon 23431, Republic of Korea

${ }^{2}$ Department of Functional crop, National Institute of Crop Science Milyang, 627-803, Republic of Korea

This is an Open Access article distributed under the terms of the Creative Commons Attribution Non-Commercial License (http://creativecommons. org/licenses/by-nc/3.0/) which permits unrestricted non-commercial use, distribution, and reproduction in any medium, provided the original work is properly cited.

\section{서 론}

콩(Glycine $\max$ )은 우리나라에서 삼국시대부터 재배되어 왔으며, 아시아 지역에서 밭에서 나는 고기로 일컬어지며 주요 식자원 으로써 이용되어 왔다. 보리, 쌀 등의 곡류를 주식으로 하는 우 리나라 식생활에서도 쌀 다음으로 소비되고 있으며, 혼반용, 콩 나물, 장류, 두부 등 다양한 방식으로 섭취되어 예로부터 식물 성 단백질 공급원으로써 주요한 역할을 해왔다[1].

콩은 수확 직후 약 20 25\%의 수분함량을 가지고 있으며, 이 로 인해 운송 및 저장이 어렵다. 따라서 콩은 수확 후 대부분 열풍건조나 천일건조를 통해 건조한 콩으로 유통이 이루어진다 [2-5]. 이러한 건조 콩은 수화하여 이후 가공공정에 사용하게 된 다. 이러한 수화 콩의 품질 및 가공적성은 콩의 수분함량에 따 라 달라지기 때문에 수화 시간 및 온도 등의 공정 변수에 그 품질이 달라지게 된다[6-8]. 하지만 콩의 수화 시 콩의 수화 특 성이 명확히 구명되지 않은 상태에서 수화가 행해지기 때문에 비용을 최소화 하고 콩의 품질을 적정수준으로 유지하기 위해 서는 콩의 수화특성이 명확히 규명되어야 한다.

수화 공정은 운동량, 물질, 열 전달현상이 동시에 연관되는 공정이기 때문에[9], 수화 공정은 매우 복잡한 공정 중 하나이 다. 이러한 수화 공정은 콩의 수분함량을 증가시켜 가공 용이 성을 증가시키는 동시에 수화 시 수용성 단백질이 용출되게 된 다[10]. 이러한 수화 특성은 온도에 따라 그 차이를 나타내게 되므로 온도에 따른 콩의 수화 특성 및 단백질 용출도를 분석 하여 최적 수화 조건을 도출하는 것이 필요하다. 따라서 콩의 수화 공정 중 수분함량 변화 및 단백질 용출 특성을 규명하기 위한 수화 모델을 개발하는 것은 매우 유용하게 활용될 수 있 다. 하지만 이러한 콩의 수화 공정의 공정 변수에 따른 수화 특 성을 연구한 결과는 미미하다. 
현재 콩의 소비가 증가하고 있음에도 불구하고 콩의 수화 특 성을 분석하고 수화 온도에 따른 콩의 수화 속도 및 단백질 용 출 특성에 대한 연구가 부족한 실정이다. 수화 온도에 따른 콩 의 수화 및 단백질 용출 kinetics 분석과 예측 모델 개발을 통 해 콩의 가공적성을 고려한 콩 가공품의 품질 최적화가 가능하 다. 따라서 본 연구에서는 콩의 수화 시 수화 온도에 따른 수 분함량 변화 및 단백질 용출의 분석 및 모델을 개발하였고, 이 를 이용하여 콩의 품질을 고려한 최적 수화공정을 개발하였다.

\section{재료 및 방법}

\section{실험재료}

본 연구에서는 국립식량과학원으로부터 국내산 백태를 제공받 아 실험을 위해 사용되었다. 콩의 초기 수분함량과 초기 단백 질 함량은 각각 $13.6 \%( \pm 0.7)$ (d.b.) 및 $39.7 \%( \pm 1.7)$ (d.b.)이었 으며, 실험기간 동안 수분함량변화를 방지하기 위하여 상온에서 진공 포장하여 보관하였다.

\section{수화공정}

콩의 수화 특성을 분석하기 위해 지름 $7.5 \mathrm{~mm}( \pm 0.1)$ 의 콩 $30 \mathrm{~g}$ 을 진탕 항온 수조(BS-11, Jeio Tech, Korea) 내의 비커에 서 $1 \mathrm{~L}$ 의 증류수를 사용하여 수화하였다. 수화 온도는 25,35 , 그리고 $45^{\circ} \mathrm{C}$ 를 사용하였고, 수화 시간은 $0,1,2,3,4,6,9$, 12,16 그리고 20 시간으로 하여 각 수화 시간에 따라 콩의 수 분함량 변화 및 단백질 용출량을 측정하였다. 수화시간에 따른 콩의 수분함량은 $105{ }^{\circ} \mathrm{C}$ 오븐 건조법 [11]을 이용하여 측정하였 으며, 단백질 용출량은 콩 수화 용액의 단백질 농도를 Bradford 방법[12]을 이용하여 측정하였다.

\section{수화 속도 분석}

수화 초기, 수화 중, 그리고 수화 종료 시점의 수화 속도는 Guine과 Fernandes[13]의 방법에 따라 계산되었다:

$$
\begin{aligned}
& t=t_{0} \text { 에서, } \\
& \frac{d M}{d t}=\frac{M_{i}-M_{0}}{t_{1}-t_{0}} \\
& t=t_{i}(t=1,1, \ldots, n-1) \text { 에서, } \\
& \frac{d M}{d t}=\frac{M_{i+1}-M_{i-1}}{t_{i+1}-t_{i-1}} \\
& t=t_{n} \text { 에서, } \\
& \frac{d M}{d t}=\frac{M_{n}-M_{n-1}}{t_{n}-t_{n-1}}
\end{aligned}
$$

여기서 $M$ 은 수화시간에 따른 수분함량 $(\mathrm{g} / \mathrm{g} \mathrm{d.b}),. M_{i}$ 는 수화시 간 $t_{i}$ 에서의 수분함량 $(\mathrm{g} / \mathrm{g}$ d.b. $), M_{0}$ 과 $t_{0}$ 은 각각 초기 수분함량 과 초기 수화시간을 뜻한다.

\section{수화 및 단백질 용출 모델}

콩의 수화 공정에서 수화 온도에 따른 수화 특성 및 단백질 용
출 특성을 분석하기 위해 Peleg가 제안한 다음과 같은 실험 모 델이 이용 되었다[14]:

$$
A=A_{i}+\frac{t}{K_{1}+K_{2} t}
$$

여기서 $A$ 는 수분함량 $\left(\mathrm{g} / \mathrm{g}\right.$ d.b.) 또는 단백질 용출량 $(\mathrm{g} / \mathrm{g} \mathrm{d.b.}), A_{i}$ 는 초기 수분함량 (g/g d.b.) 또는 단백질 용출량 $(\mathrm{g} / \mathrm{g}$ d.b. $)$, $t$ 는 수화 시간 $(\mathrm{min}), K_{1}$ 과 $K_{2}$ 는 Peleg 상수를 뜻한다. Peleg 상수 $K_{2}$ 는 해당 수화 조건에서의 최대 도달 가능한 수분함량 또는 단백질 용출량과 연관이 있다. 따라서 수화시간 $t$ 가 무한대가 됨에 따라, 포화수분함량 및 단백질 최대 용출량은 다음 수식 에 의해 표현될 수 있다:

$$
\left.A\right|_{t_{\infty}}=A_{e}=A_{i}+\frac{1}{K_{2}}
$$

Peleg 상수를 도출하기 위해 Eq. (5)를 선형화 하여 다음과 같 은 수식을 도출한다:

$$
\frac{t}{\left(A-A_{i}\right)}=K_{1}+K_{2} t
$$

시간에 따른 $\frac{t}{\left(A-A_{i}\right)}$ 를 분석하여 선형 모델의 절편과 기울기를 통해 각각 $K_{1}$ 과 $K_{2}$ 를 얻게 된다. 이러한 Peleg 모델은 다양한 식품의 공정 분석에 이용되고 있다 $[6,7,15,16]$.

\section{통계분석}

모든 실험은 반복하여 3 회 측정하였으며, 실험결과의 통계분석 은 MS-Excel-2016의 분산분석(ANOVA)을 이용하여 $p<0.05$ 수 준에서 유의차를 분석하였다.

\section{결과 및 고찰}

\section{수화 kinetics}

수화 온도가 콩의 수화 kinetics에 미치는 영향을 조사하기 위 하여 콩을 45,35 그리고 $25^{\circ} \mathrm{C}$ 의 수화 온도에서 수화하여 그 수분함량 변화를 분석하였다. 콩의 수화 공정에서 수화 온도에 따라 콩의 수분함량은 유의적인 차이를 나타내었으며, 이는 수 화 온도가 콩의 수화 kinetics에 영향을 미침을 뜻한다(Fig. 1). 수화 온도가 증가함에 따라 수분 증가량 또한 증가하였으며, 이 는 콩을 목표수분함량까지 수화하기 위해 필요한 시간이 감소 됨을 의미한다.

수화 온도에 따른 콩의 수화 속도를 비교한 결과를 Fig. 2에 나타내었다. 수화 공정 중의 수분함량 변화 속도는 수분함량을 기초로 하는 Eqs. (1)-(3)를 통해 계산되었다. 모든 수화 온도에 서, 수화 속도는 수화시간이 증가함에 따라 수화 속도가 감소 하는 결과를 나타내었으며, 수화 시간에 따른 수화 속도가 일 정한 항률 수화 기간은 나타나지 않았다. 콩은 체적당 표면적 이 매우 큰 재료로, 콩 표면에서의 수분함량이 수화의 시작과 함께 매우 빠른 속도로 증가하게 되므로 수화 초기부터 감률 수화 기간을 보여주었다. 이러한 감률 수화 양상은 콩류의 수 화 공정에서 나타나는 전형적인 양상이며, 다양한 콩류의 수화 


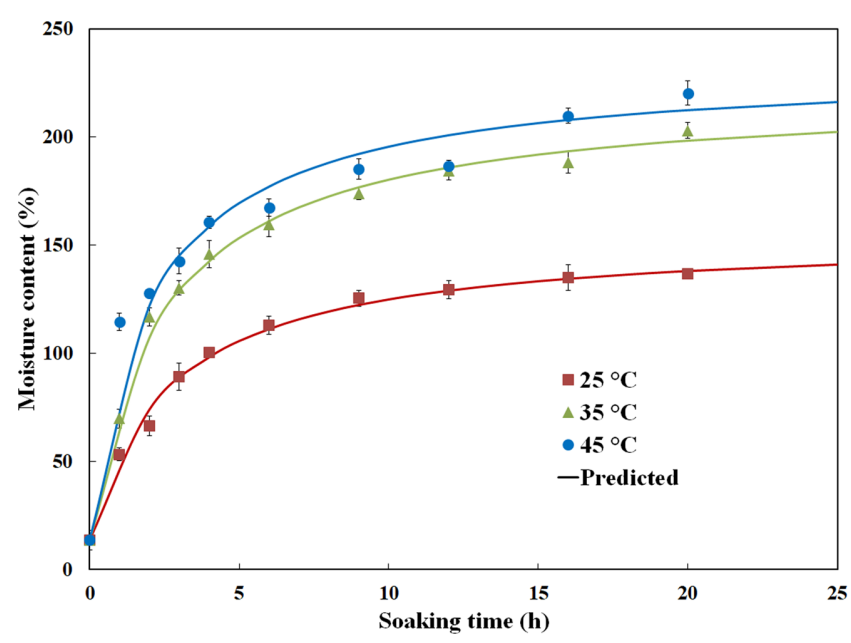

Fig. 1 Changes in the moisture content of soybean during soaking

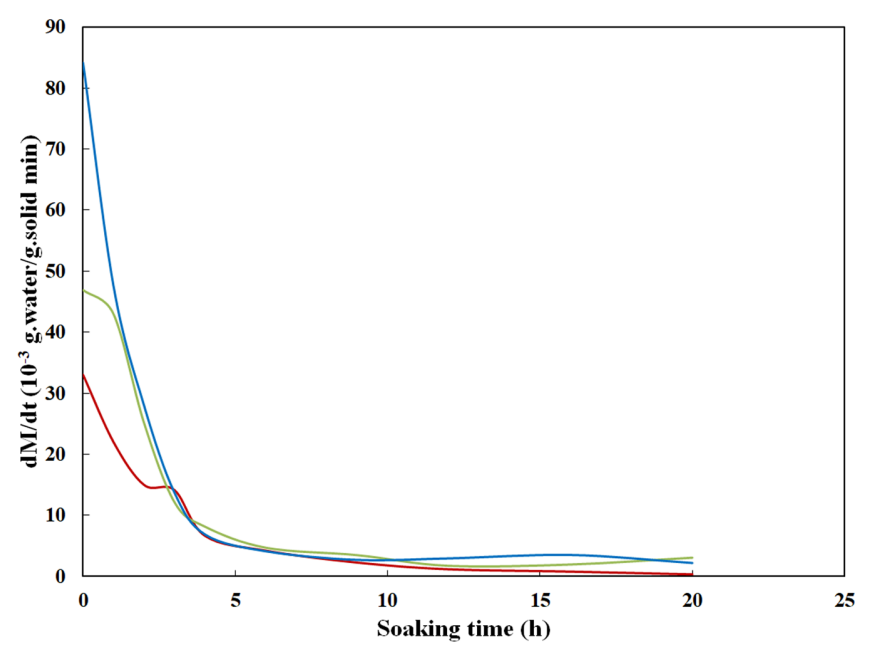

Fig. 2 Effect of soaking temperature on the changes of soaking rate

공정에서 관찰된 바 있다[17-20]. 피수화물의 표면층은 일정한 수분함량을 유지할 수 없기 때문에, 수화 속도는 피수화물의 외 부에서 내부로 이동하는 수분의 확산에 의존하게 된다[7,17].

\section{수화 분석 모델}

수화 온도에 따른 콩의 수분함량 변화를 분석하기 위해서, Peleg 모델을 이용하여 콩의 수화 특성을 분석하였다. Peleg 모델을 콩의 수화 공정 중 수분함량 변화를 분석하기 위해 적용하였을 시, 수화 온도에 상관없이 높은 $R^{2}$ 값 $(>0.991)$ 을 나타내어 콩의 수화 특성을 분석하기에 적합함을 나타내었다(Table $1 \mathrm{~A}$ and Fig. 1). Peleg 상수 $K_{1}$ 은 수화 속도와 관련된 변수로, 수화 속 도와 반비례하는 결과를 나타내게 된다. 콩의 수화 공정에서, 수화 온도가 25 에서 $45^{\circ} \mathrm{C}$ 로 증가함에 따라 $K_{1}$ 은 0.0189 에서 0.00932 로 감소하여 수화 온도가 증가함에 따라 수화 속도가 빨 라짐을 확인하였다. 이와 달리 $K_{2}$ 는 콩 수화에서 포화수분함량 과 관련된 상수로, 이 또한 역시 포화수분함량과 반비례하는 상 관관계를 가지게 된다. $K_{2}$ 를 이용해 평가된 포화수분함량은 수
Table 1A Model parameters from the Peleg model to describe the soaking kinetics of soybean

\begin{tabular}{ccccc}
\hline \hline Model name & $\begin{array}{c}\text { Temperature } \\
\left({ }^{\circ} \mathrm{C}\right)\end{array}$ & $K_{1}$ & $K_{2}$ & $R^{2}$ \\
\hline \multirow{3}{*}{ Peleg model } & 25 & 0.0189 & 0.00709 & 0.998 \\
& 35 & 0.0117 & 0.00483 & 0.997 \\
& 45 & 0.00932 & 0.00456 & 0.991 \\
\hline
\end{tabular}

Table 1B Model parameters from the Peleg model to describe the protein loss kinetics of soybean

\begin{tabular}{ccccc}
\hline \hline Model name & $\begin{array}{c}\text { Temperature } \\
\left({ }^{\circ} \mathrm{C}\right)\end{array}$ & $K_{1}$ & $K_{2}$ & $R^{2}$ \\
\hline \multirow{3}{*}{ Peleg model } & 25 & 0.0816 & 0.0219 & 0.941 \\
& 35 & 0.0237 & 0.00311 & 0.961 \\
& 45 & 0.0183 & 0.00180 & 0.952 \\
\hline
\end{tabular}

화 온도가 25 에서 $45^{\circ} \mathrm{C}$ 로 증가함에 따라 154.7 에서 $232.8 \%$ 로 증가하여 수화 온도에 증가함에 따라 포화수분함량이 급격히 증 가하는 것을 확인할 수 있었다. 본 연구에서 개발된 모델을 이 용하여, 목표수분함량에 도달하기 위해 필요한 수화 시간이 도 출될 수 있다. 각 수화 온도 별 목표수분함량 $(130 \%)$ 에 도달하 기 위해 필요한 시간은 각각 $25^{\circ} \mathrm{C}$ 에서 12.6 시간, $35^{\circ} \mathrm{C}$ 에서 3.11 시간, 그리고 $45^{\circ} \mathrm{C}$ 에서 2.31 시간을 나타내어 수화 온도가 증가함에 따라 수화에 필요한 시간이 줄어드는 것을 확인할 수 있었다. 목표수분함량에 도달하기 위해 필요한 수화 시간을 감 소 시키기 위해 수화 온도를 높여 수화 속도를 증가시킬 수 있 다. 하지만, 높은 수화 온도에서 수화 공정 중 콩의 수용성 단 백질 용출 속도 또한 빨라질 수 있으므로 수화 공정은 이러한 콩의 품질을 고려하여 최적화되어야 한다.

\section{단백질 용출 kinetics}

수화 온도가 콩의 수화 중 수용성 단백질 함량에 미치는 영향 을 확인하기 위해 수화 온도 및 시간에 따른 단백질 용출량을 분석하였다. 콩의 수화 공정에서 수화온도에 따라 단백질 용출 량은 유의적인 차이를 나타내었으며, 이는 수화 온도가 단백질 용출 kinetics에 영향을 미치는 것을 의미한다(Fig. 3). 수화 온 도가 증가함에 따라 수화 시간에 따른 단백질 용출량이 급격하 게 증가하였으며, 콩의 품질을 고려한 수화공정 개발을 위해 콩 의 수화 온도에 따른 수화 kinetics 및 단백질 용출 kinetics가 함께 고려되어야 하는 것을 의미하게 된다.

수화 온도에 따른 콩의 수용성 단백질 용출 kinetics를 분석 하기 위해서, Peleg 모델을 적용하였다. 콩의 수화 공정 중 단 백질 용출량 변화를 분석하기 위해 Peleg 모델을 적용하였을 시, 수화 온도에 상관없이 높은 $R^{2}$ 값 $(>0.941)$ 을 나타내어 수화 공 정에서 콩의 단백질 용출 특성을 분석할 수 있었다(Table $1 \mathrm{~B}$ and Fig. 3). 이러한Peleg 모델의 변수를 분석하여, 수화 온도에 따른 단백질 용출 kinetics변화를 확인할 수 있다. Peleg 상수 $K_{1}$ 은 수화 중 단백질 용출 속도를 판단할 수 있는 인자이며, 단 백질 용출 속도와 반비례하는 값을 가지게 된다. 콩의 수화 공 정에서, 수화 온도가 45 에서 $25^{\circ} \mathrm{C}$ 로 감소함에 따라 $K_{1}$ 은 0.0183 에서 0.0816 으로 증가하여 수화 온도가 감소함에 따라 수 


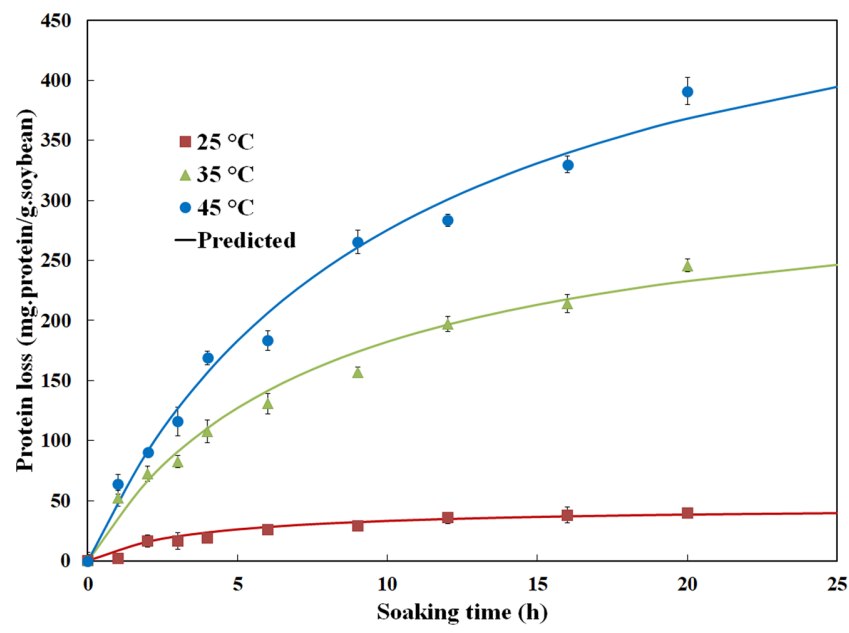

Fig. 3 Change in the protein loss of soybean during soaking

화 중 발생하는 단백질 용출 속도를 낮출 수 있음을 확인하였 다. $K_{2}$ 는 콩의 수화 공정에서 최대로 용출될 수 있는 단백질량 을 판단하는 상수로, Eq. (5)에 의해 단백질 최대 용출량이 평 가될 수 있다. Peleg 모델을 통해 계산된 단백질 최대 용출량 은 수화 온도가 25 에서 $45^{\circ} \mathrm{C}$ 로 증가함에 따라 $45.6 \mathrm{mg} / \mathrm{g}$ 에서 $554.6 \mathrm{mg} / \mathrm{g}$ 으로 증가하여 수화 온도에 증가함에 따라 단백질 최 대 용출량이 급격히 증가하는 것을 확인할 수 있었다. 콩의 수 화 공정에서 단백질 용출 결과는 콩의 품질을 고려한 수화 공 정 개발을 위해, 수화 조건에 따른 수분함량 변화 외에 단백질 용출량 또한 고려되어야 함을 보여주었다.

콩의 품질을 고려한 수화 공정 개발을 위하여, 콩의 수분함 량에 따른 단백질 용출량을 분석하였다(Fig. 4). Fig. 4에서 나 타난 바와 같이, 수화 온도가 증가함에 따라 수화에 소요되는 시간이 감소함에도 불구하고 수화 온도가 낮을수록 단백질 용 출량이 감소하는 결과를 나타내었다. 이러한 결과는 온도에 따 른 반응 속도의 변화가 단백질 용출량이 더 큰 것을 의미하며, 수화온도가 25 에서 $45{ }^{\circ} \mathrm{C}$ 로 증가함에 따라 수분함량에 대한 $K_{1}$ 값은 0.0189 에서 0.00932 로 감소한 반면 단백질 용출에 대한 $K_{1}$ 값은 0.0816 에서 0.0183 으로 급격히 감소한 분석 결과에서도 확인할 수 있다(Table 1). 수화온도에 따른 콩의 최종 품질을 판단하기 위해 수분함량과 단백질 용출 분석 모델들을 통합하 여 목표 수분함량에서의 단백질 용출량을 계산하였으며, 그 값 은 수화온도 $25^{\circ} \mathrm{C}$ 에서 $35.2 \mathrm{mg} / \mathrm{g}, 35^{\circ} \mathrm{C}$ 에서 $93.1 \mathrm{mg} / \mathrm{g}$ 그리고 $45^{\circ} \mathrm{C}$ 에서는 $103.0 \mathrm{mg} / \mathrm{g}$ 을 나타내어 본 연구에서 콩을 품질을 고려한 최적 수화 조건은 $25^{\circ} \mathrm{C}$ 에서 12.6 시간의 수화 시간이 적 용되어야 하는 것을 확인하였다.

\section{초 록}

콩의 수화 공정에서 수화 온도에 따른 수분함량의 변화 및 단 백질 용출을 분석하기 위하여 콩의 수화 특성 및 단백질 용출 특성을 확인하였다. 수화 온도가 증가함에 따라 콩의 수화 속 도는 증가하는 경향을 나타내었으며, 이러한 수화 특성이 Peleg

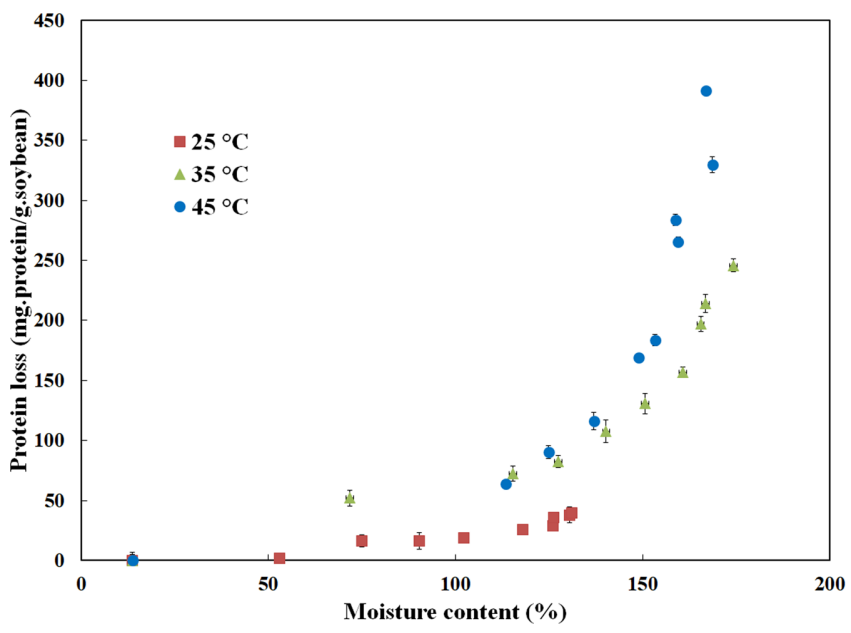

Fig. 4 Effect of soaking temperature on the changes in the protein loss according to the moisture content

모델을 통해 분석되었다 $\left(R^{2}>991\right)$. 초기수분함량으로부터 목표수 분함량 $(130 \%)$ 까지 수화시키기 위해 25,35 그리고 $45^{\circ} \mathrm{C}$ 수화 에서 필요한 수화시간은 각각 $12.6,3.11$, 그리고 2.31 시간을 나 타내어 수화 온도가 증가함에 따라 목표함량에 도달하기 위한 수화시간이 급격히 짧아지는 것을 확인할 수 있었다. 수화공정 에 따른 콩의 품질을 분석하기 위해 수화에 따른 단백질 용출 량 또한 확인하였으며, 이 또한 Peleg 모델을 이용하여 분석하 였다 $\left(R^{2}>0.941\right)$. 단백질 용출 속도는 수화 온도가 증가함에 따 라 증가하는 경향을 나타내었으며, 수화 온도가 증가함에 따라 수화에 필요한 시간도 줄어들지만 그에 따른 단백질 용출량 또 한 증가하는 것을 확인할 수 있었다. 수분함량과 단백질 용출 을 분석하기 위해 개발된 두 모델을 이용하여 목표수분함량까 지 수화하였을 때의 콩의 단백질 용출량을 분석하였으며, 25 , 35 그리고 $45^{\circ} \mathrm{C}$ 에서 각각 $35.2,93.1$ 그리고 $103.0 \mathrm{mg} / \mathrm{g}$ 을 나 타내어, $25^{\circ} \mathrm{C}$ 의 수화온도에서 12.6 시간의 수화시간이 콩의 품 질을 고려한 최적 수화공정임을 확인하였다.

Keywords 단백질 용출 · 동역학 모델 - 수분확산 · 수화공정

Acknowledgments 본 성과물은 농촌진흥청 연구사업(세부과제번호: PJ012544022019)의 지원에 의해 이루어진 것임.

\section{References}

1. Kwon SH (1972) Origin and importance of protein and oil of Korean soybean. Korean J Food Sci Technol 4(2): 158-161

2. Park HW, Yoon WB (2019) Prediction of the intermittent drying behavior of soybeans [Glycine max (L.)] using novel multilayerd mass transfer simulation with an image analysis. Drying Technol 37(10): 1228-1238

3. Park HW, Han WY, Yoon WB (2018) Drying characteristics of soybean (Glycine max) using continuous drying and intermittent drying. Int $\mathrm{J}$ Food Eng 14(9-10)

4. Rafiee S, Sharifi M, Keyhani A, Omid M, Jafari A, Mohtsebi S, Mobli H (2010) Modeling effective moisture diffusivity of orange slice (Thompson Cv.). Int J Food Prop 13(1): 32-40 
5. Soponronnarit S, Swasdisevi T, Wetchacama S, Wutiwiwatchai W (2001) Fluidised bed drying of soybeans. J Stored Prod Res 37(2): 133151

6. Pan Z, Tangratanavalee W (2003) Characteristics of soybean as affected by soaking conditions. LWT-Food Sci Technol 36: 143-151

7. Park HW, Yoon WB (2018) Development of a novel image analysis technique to detect the moisture diffusion of soybeans [Glycine $\max (\mathrm{L}$.)] during rehydration using a mass transfer simulation model. Food Bioprocess Tech 11(10): 1887-1894

8. Seo J, Lee S (2004) Production of fibrinolytic enzyme from soybean grits fermented by Bacillus firmus NA-1. J Med Food 7(4): 442-449

9. Yilbas BS, Hussain MM, Dincer I (2003) Heat and moisture diffusion in slab products to convective boundary conditions. Heat Mass Transfer 39: 471-476

10. Lima FS, Kurozawa LE, Ida EL (2014) The effects of soybean soaking on grain properties and isoflavones loss. LWT-Food Sci Technol 59(2): $1274-1282$

11. AOAC (1990) Official methods of Analysis, $15^{\text {th }}$ ed. Association of Official Analytical Chemists: Washington, D.C., USA

12. Bradford M (1976) A rapid and sensitive method for quantification of microgram quantities of protein utilizing the principle of protein-dye binding. Anal Biochem 72: 248-254

13. Guine RPF, Fernandes RMC (2006) Analysis of the drying kinetics of chestnuts. J Food Eng 76: 460-467

14. Peleg M (1988) An empirical model for description of moisture sorption curves. J Food Sci 41: 57-72

15. Rafiq A, Chowdhary J, Hazarika MK, Makroo HA (2015) Temperature dependence on hydration kinetic model parameters during rehydration of parboiled rice. J Food Sci Technol 52(9): 6090-6094

16. Marques BC, Jorge LMM, Jorge RMM (2016) Chemical properties and water absorption kinetics of transgenic corn grain (2B587 Hx) and its conventional isoline (2B587). J Cereal Sci 71: 93-98

17. Abu-Ghannam N, McKenna B (1997) Hydration kinetics of red kidney beans. J Food Sci 62(3): 520-523

18. Jideani VA, Mpotokwana SM (2009) Modeling of water absorption of Botswana Bambara varieties using Peleg's equation. J Food Eng 92(2): $182-188$

19. Seyhan-Gürtaş F, Mehmet AK, Evranuz ÖE (2001) Water diffusion coefficients of selected legumes grown in Turkey as affected by temperature and variety. Turk J Agric For 25(5): 297-304

20. Sopade PA, Ajisegiri ES, Badau MH (1992) The use of Peleg's equation in some cereal grains during soaking. J Food Eng, 15: 269-283 